JIIA, VOLUME 6, No. 1, FEBRUARI 2018

\title{
KINERJA LUMBUNG PANGAN DALAM MENDUKUNG KETERSEDIAAN PANGAN RUMAH TANGGA DI KABUPATEN PRINGSEWU
}

(Performance of Food Granary in Supporting Household Food Availability in Pringsewu Regency)

Mahmud Rifa'i, Fembriarti Erry Prasmatiwi, Indah Nurmayasari

Jurusan Agribisnis, Fakultas Pertanian, Universitas Lampung, J1. Prof. Dr. Soemantri Brojonegoro No. 1 Bandar Lampung, 35145. Telp.085769907575, e-mail:mahmudrifai1995@gmail.com

\begin{abstract}
This research aims to analyze the mechanism of food granary in supporting household food availability, performance of food granary institution, and factors that affect the performance of the food granary in Ambarawa Subdistrict Pringsewu Regency. The location was determined purposively with consideration that Ambarawa Subdistrict is one district which has a lot of active food granary institutions. Data were collected in September 2016. The samples were determined proportionately randomly, as many as 30 active food granaries in Ambarawa village, Ambarawa Barat village, and Sumber Agung village. This research used a survey method, and the data were analyzed using qualitative and quantitative descriptive analysis. The results showed that the mechanism of food granary was realized by saving and borrowing of unhusk rice. The members of food granary can borrow as much as 100-1,000 kilograms of rice per year. They borrow rice at the time of scarcity before harvest time, and save rice after harvest time. The results showed that the performance of 46.67 percent of food granaries are categorized in a low level and 53.33 percent in medium level. Factors that affect the performance of food granary in Ambarawa Subdistrict, Pringsewu Regency, are the age of food granary, the number of members, and the kind of food granary.
\end{abstract}

Key words: food availability, food granary, performance.

\section{PENDAHULUAN}

Indonesia merupakan negara berkembang dengan laju pertumbuhan penduduk yang tinggi yakni 1,49 persen per tahun (BPS Republik Indonesia 2016). Peningkatan populasi penduduk di Indonesia diikuti oleh peningkatan permintaan pangan, sehingga Indonesia dituntut untuk dapat meningkatkan ketersediaan pangan masyarakat. Kebutuhan akan pangan menjadi aspek penting yang harus diprioritaskan oleh pemerintah, karena kondisi pemenuhan kebutuhan pangan masyarakat di suatu negara dapat menjadi gambaran tingkat kesejahteraan masyarakat di negara tersebut.

Indonesia merupakan salah satu negara agraris terbesar di dunia dengan hasil produksi pertanian yang tinggi. Salah satu komoditi pertanian di Indonesia adalah padi. Produksi padi di Indonesia selama lima tahun mengalami fluktuasi dengan perkembangan sebesar 14 persen (BPS Republik Indonesia 2016). Angka tersebut menunjukkan terjadinya peningkatan terhadap produksi padi dalam negeri. Peningkatan produksi padi ternyata masih belum mampu memenuhi kebutuhan pangan masyarakat, karena Indonesia masih tetap mengimpor beras untuk memenuhi kebutuhan pangan masyarakatnya.

Impor beras di Indonesia pada tahun 2011 - 2015 mengalami perkembangan negatif, yang artinya terdapat penurunan jumlah impor beras yang dilakukan Indonesia (BPS Republik Indonesia 2016). Jumlah impor beras memang telah mengalami penurunan, akan tetapi Indonesia masih bergantung pada impor. Hal ini mengindikasikan bahwa Indonesia memerlukan suatu sistem pengelolaan stok pangan yang lebih efisien, baik pada tingkat nasional maupun tingkat rumah tangga petani, agar dapat menghindarkan masyarakat dari masalah ketersediaan pangan.

Masalah ketersediaan pangan pada tingkat masyarakat petani di pedesaan masih menjadi isu strategis. Hal tersebut karena mayoritas petani di pedesaan menjalankan usahataninya pada skala kecil akibat keterbatasan kepemilikan lahan dan modal usaha. Keadaan tersebut memaksa petani untuk meminjam modal usahatani, sehingga pada saat panen, petani langsung menjual hasil panen untuk membayar hutang modal usahataninya (Mardalis dan Rosyadi 2015). 
Petani membutuhkan suatu kelembagaan yang tidak hanya membantu dalam hal pemasaran hasil pertanian, tetapi juga penyediaan stok pangan saat musim paceklik. Berbagai lembaga pemasaran hasil pertanian seperti koperasi, koperasi unit desa, ataupun pasar lelang, memang dapat membantu petani dalam hal perbaikan harga, tetapi tidak dapat membantu petani dalam hal mengatasi risiko kegagalan panen dan memenuhi kebutuhan pangan masyarakat sepanjang tahun. Berdasarkan hal itulah, maka alternatif terbaik untuk permasalahan tersebut adalah menghidupkan dan mengelola kembali lumbung pangan masyarakat yang ada di pedesaan.

Lumbung pangan adalah suatu kelembagaan pangan masyarakat yang berperan dalam menyediakan stok pangan pada saat musim paceklik atau saat terjadi gagal panen. Lumbung pangan berfungsi sebagai pengelola cadangan pangan, dan penyangga harga gabah, karena anggota lumbung biasanya akan meminjam gabah saat musim paceklik dan mengembalikannya pada saat panen (Mardalis dan Rosyadi 2015). Dengan demikian, petani tidak perlu lagi menjual gabah saat panen ketika harga gabah sangat rendah.

Kabupaten Pringsewu merupakan salah satu sentra penghasil tanaman pangan dan memiliki banyak lumbung pangan yang masih aktif beroperasi, yang terletak di Kecamatan Ambarawa. Menurut BP3K Kecamatan Ambarawa tahun 2015, terdapat 58 lumbung pangan yang tersebar di tujuh desa. Peran lumbung pangan dapat berjalan dengan baik apabila kinerja lumbung pangan tersebut juga baik. Menurut Departemen Pertanian (2008) lumbung pangan diklasifikasikan ke dalam tiga kategori, yakni lumbung sederhana, lumbung maju, dan lumbung pangan modern.

Nasdian (2006) menyebutkan bahwa terdapat permasalahan pokok yang sering dihadapi oleh lumbung pangan, yang meliputi lemahnya kapasitas kelembagaan dari komunitas petani pedesaan, rendahnya partisipasi, rendahnya dukungan teknis serta lemahnya sinergi dari kelembagaan lainnya, seperti pemerintah, pihak swasta, lembaga swadaya masyarakat maupun perguruan tinggi. Lebih lanjut, Basri (2008) juga mengungkapkan bahwa suatu kelembagaan lumbung pangan masyarakat di pedesaan juga sering mengalami masalah seperti dalam hal permodalan, bantuan pemerintah, rendahnya pendidikan para pengurus, rendahnya pendapatan pengurus, lemahnya sinergi dari kelembagaan lain, serta berbagai hal lain.
Berbagai hal tersebut pada akhirnya akan mempengaruhi suatu lumbung pangan dalam mendukung ketersediaan pangan anggotanya. Berdasarkan kondisi tersebut, maka perlu dilakukan penelitian tentang kinerja lumbung pangan dalam mendukung ketersediaan pangan rumah tangga di Kecamatan Ambarawa Kabupaten Pringsewu. Tujuan dari penelitian ini yakni menganalisis mekanisme lumbung pangan dalam mendukung ketersediaan pangan rumah tangga, menganalisis kinerja lumbung pangan masyarakat, dan menganalisis faktor yang mempengaruhi kinerja lumbung pangan masyarakat di Kecamatan Ambarawa Kabupaten Pringsewu.

\section{METODE PENELITIAN}

Penelitian ini dilakukan dengan metode survei. Pengambilan data pada penelitian ini dilakukan di Kecamatan Ambarawa Kabupaten Pringsewu. Pemilihan lokasi dilakukan secara sengaja atau purposive dengan pertimbangan bahwa Kecamatan Ambarawa merupakan daerah dengan keberadaan lumbung pangan aktif dengan jumlah terbanyak di Provinsi Lampung, baik lumbung swadaya maupun lumbung pangan bentukan/buatan pemerintah. Pengambilan data dilakukan pada September 2016. Responden pada penelitian ini adalah pengurus lumbung pangan di Kecamatan Ambarawa Kabupaten Pringsewu.

Jumlah lumbung pangan di Kecamatan Ambarawa mayoritas berada pada tiga desa yakni di Desa Ambarawa (10 lumbung), Desa Ambarawa Barat (27 lumbung), dan di Desa Sumber Agung (sembilan lumbung). Berdasarkan hal tersebut maka sampel pada penelitian ini diambil dari tiga desa tersebut secara proporsional (proportionate random sampling). Menurut pendapat Irianto dan Mardikanto (2010) apabila proporsi besarnya sub populasi telah diketahui, maka sebaiknya jumlah sampel untuk setiap kelompok terkecil ditetapkan secara proporsional. Penetapan jumlah sampel penelitian juga harus disesuaikan dengan analisis yang akan digunakan. Untuk jenis analisis non parametrik, jumlah sampel dapat ditetapkan kurang dari 30 sampel, sedangkan untuk analisis parametrik seperti pada penelitian ini, sampel yang diambil bisa berjumlah minimal 30 sampel.

Berdasarkan hal tersebut, peneliti menetapkan sampel sebanyak 30 lumbung pangan dari tiga desa dengan populasi lumbung terbanyak. Perhitungan pengambilan sampel penelitian secara proporsional untuk setiap desa lokasi penelitian mengacu pada rumus berikut (Saryono 2010) : 
$\mathrm{n}_{\mathrm{a}}=\frac{\mathrm{N}_{\mathrm{a}}}{\mathrm{N}} \mathrm{xn}$

Keterangan:

na $=$ Jumlah lumbung yang akan diambil dari masing - masing desa

$\mathrm{n} \quad=$ Jumlah sampel lumbung (keseluruhan)

$\mathrm{Na}=$ Jumlah populasi lumbung di masing masing desa

$\mathrm{N}=$ Jumlah populasi lumbung keseluruhan (di tiga desa)

Berdasarkan pada perhitungan menggunakan rumus tersebut, maka sampel sebanyak 30 lumbung pangan tersebar secara proporsional yang meliputi enam lumbung di Desa Ambarawa, 18 lumbung di Desa Ambarawa Barat, dan enam lumbung di Desa Sumber Agung. Data yang digunakan dalam penelitian ini merupakan data primer dan data sekunder. Data primer diperoleh dari hasil wawancara kepada responden, sedangkan data sekunder diperoleh dari berbagai sumber yang berhubungan dengan penelitian ini. Analisis data pada penelitian ini dilakukan secara kualitatif dan kuantitatif. Analisis deskriptif kualitatif dilakukan untuk mengetahui tujuan penelitian pertama dan kedua. Analisis kuantitatif digunakan untuk mengetahui tujuan penelitian poin ketiga, yakni faktor-faktor yang mempengaruhi kinerja lumbung masyarakat di Kecamatan Ambarawa Kabupaten Pringsewu.

Mekanisme lumbung pangan dianalisis dari kegiatan yang dilakukan oleh lumbung pangan. Kegiatan tersebut meliputi kegiatan pengumpulan gabah sebagai modal awal berdirinya lumbung pangan, peminjaman gabah oleh anggota lumbung pangan, pembongkaran lumbung pangan dan pembagian pinjaman gabah. Kegiatan lainnya yakni pengembalian pinjaman gabah anggota yang dilakukan setiap musim panen, dan penghitungan manfaat lumbung pangan bagi para anggotanya.

Kinerja lumbung pangan diukur menggunakan tiga indikator, yang meliputi indikator manajemen organisasi dan penguasaan sarana, indikator skala usaha, dan indikator hasil usaha. Masing - masing indikator memiliki parameter pengukuran, yang akan diukur dengan skor 1 - 3 seperti yang tersaji pada Tabel 1, Tabel 2, dan Tabel 3 sebagai berikut. Tabel 1 menunjukkan pengukuran kinerja dari indikator manajemen organisasi dan penguasaan sarana, yang meliputi peraturan (AD/ART), rapat pengurus, buku administrasi, lantai jemur, dan perangkat humas.
Tabel 1. Pengukuran kinerja lumbung pangan berdasarkan indikator manajemen organisasi dan penguasaan sarana

\begin{tabular}{|c|c|c|}
\hline No & Parameter & Skor \\
\hline \multirow[t]{4}{*}{1.} & Peraturan (AD/ART) & \\
\hline & Ada, belum tertulis & 1 \\
\hline & Tertulis, belum terlaksana $100 \%$ & 2 \\
\hline & Tertulis, sudah terlaksana $100 \%$ & 3 \\
\hline \multirow[t]{4}{*}{2.} & Rapat Pengurus & \\
\hline & 1 kali dalam setahun & 1 \\
\hline & 2 - 3 kali dalam setahun & 2 \\
\hline & $\geq 4$ kali dalam setahun & 3 \\
\hline \multirow[t]{4}{*}{3.} & Buku Administrasi & \\
\hline & $\begin{array}{l}\text { Buku daftar simpanan, transaksi lumbung, } \\
\text { daftar anggota }\end{array}$ & 1 \\
\hline & $\begin{array}{l}\text { Buku daftar simpanan, transaksi lumbung, } \\
\text { daftar anggota, daftar pengurus }\end{array}$ & 2 \\
\hline & $\begin{array}{l}\text { Buku daftar simpanan, transaksi lumbung, } \\
\text { daftar anggota, daftar pengurus, notulen rapat }\end{array}$ & 3 \\
\hline \multirow[t]{4}{*}{4.} & Lantai jemur & \\
\hline & Tidak punya & 1 \\
\hline & Ada, dengan terpal & 2 \\
\hline & Ada, bangunan permanen & 3 \\
\hline \multirow[t]{4}{*}{5.} & Perangkat humas (hubungan masyarakat) & \\
\hline & Tidak ada & 1 \\
\hline & Ada, 1 orang & 2 \\
\hline & Ada, $\geq 2$ orang & 3 \\
\hline
\end{tabular}

Parameter pengukuran pada indikator skala usaha meliputi jenis usaha, kapasitas lumbung, omzet lumbung, dan persentase anggota yang melakukan simpan pinjam gabah. Adapun pada indikator hasil usaha, parameter pengukuran kinerja lumbung pangan meliputi pertambahan modal, keuntungan anggota, keuntungan lumbung, insentif pengurus, pemenuhan kapasitas, hasil usaha, dan persentase pemenuhan omzet. Indikator tersebut didasarkan pada keadaan riil lumbung pangan di lokasi penelitian.

Tabel 2. Pengukuran kinerja lumbung pangan berdasarkan indikator skala usaha

\begin{tabular}{clc}
\hline No & \multicolumn{1}{c}{ Parameter } & Skor \\
\hline 1. & Jenis usaha lumbung pangan & 1 \\
& Simpan pinjam gabah & 2 \\
& Simpan pinjam gabah dan pupuk & 3 \\
& Simpan pinjam gabah, pupuk, uang, dan usaha & \\
& lainnya & \\
2. & Kapasitas lumbung pangan (ton GKG) & 1 \\
& $0-7.000$ & 2 \\
& $7.001-14.000$ & 3 \\
& $14.001-22.000$ & \\
3. & \\
& $0-5$ & 1 \\
& $5,1-10$ & 2 \\
& $>10$ & 3 \\
4. Persentase anggota yang melakukan simpan & \\
& pinjam & 1 \\
$0-50 \%$ & 2 \\
$51-99 \%$ & 3 \\
\hline
\end{tabular}


Tabel 3. Pengukuran kinerja lumbung pangan berdasarkan indikator hasil usaha

\begin{tabular}{|c|c|c|}
\hline No. & Parameter & Skor \\
\hline \multirow[t]{4}{*}{1.} & Pertambahan modal (kg/thn) & \\
\hline & $\leq 335 \mathrm{~kg}$ & 1 \\
\hline & $336 \mathrm{~kg}-638 \mathrm{~kg}$ & 2 \\
\hline & $\geq 639 \mathrm{~kg}$ & 3 \\
\hline \multirow[t]{4}{*}{2.} & Keuntungan anggota lumbung pangan (Rp) & \\
\hline & 0 - Rp.1.380.000,00 & 1 \\
\hline & Rp.1.381.000,00 - Rp.2.760.000,00 & 2 \\
\hline & Rp.2.761.000,00 - Rp. $4.150 .000,00$ & 3 \\
\hline \multirow[t]{4}{*}{3.} & Insentif Pengurus $(\mathrm{Rp})$ & \\
\hline & 0 - Rp.1.000.000,00 & 1 \\
\hline & Rp.1.000.000,00 - Rp.2.000.000,00 & 2 \\
\hline & $\geq$ Rp.2.000.000,00 & 3 \\
\hline \multirow[t]{4}{*}{4.} & Keuntungan lumbung pangan (kg GKG) & \\
\hline & $0-1.000$ & 1 \\
\hline & $1.001-2.000$ & 2 \\
\hline & $>2.000$ & 3 \\
\hline \multirow[t]{4}{*}{5.} & Pemenuhan kapasitas lumbung pangan (\%) & \\
\hline & $0-50$ & 1 \\
\hline & $51-99$ & 2 \\
\hline & $\geq 100$ & 3 \\
\hline \multirow[t]{4}{*}{6.} & Hasil usaha lumbung pangan (ton GKG) & \\
\hline & $0-3$ & 1 \\
\hline & $3,1-5$ & 2 \\
\hline & $>5$ & 3 \\
\hline \multirow[t]{4}{*}{7.} & Omzet yang dipinjam anggota $(\%)$ & \\
\hline & $0-50$ & 1 \\
\hline & $51-99$ & 2 \\
\hline & $\geq 100$ & 3 \\
\hline
\end{tabular}

Parameter tersebut terlebih dahulu diuji validitas dan reliabilitasnya sebelum digunakan untuk mengukur kinerja lumbung pangan. Uji validitas dan reliabilitas digunakan untuk mengukur sah atau tidaknya suatu pertanyaan penelitian yang tertera pada kuesioner penelitian. Uji validitas dan reliabilitas dilakukan menggunakan program SPSS. Hasil uji validitas dan reliabilitas terhadap parameter kinerja lumbung tersaji pada Tabel 4.

Tabel 4. Hasil uji validitas dan reliabilitas dari parameter pengukuran kinerja lumbung

\begin{tabular}{clc}
\hline No. & Parameter pengukuran kinerja & Extraction Value \\
\hline 1. & Peraturan (AD/ART) & 0,763 \\
2. & Rapat pengurus & 0,681 \\
3. & Buku administrasi & 0,840 \\
4. & Lantai jemur & 0,817 \\
5. & Perangkat humas & 0,777 \\
6. & Jenis usaha & 0,502 \\
7. & Kapasitas lumbung & 0,861 \\
8. & Omzet lumbung & 0,723 \\
9. & Persentase anggota & 0,834 \\
10. & Hasil usaha & 0,810 \\
11. & Insentif pengurus & 0,895 \\
12. & Pertambahan modal & 0,823 \\
13. & Keuntungan anggota & 0,637 \\
14. & Keuntungan lumbung & 0,753 \\
15. & Persentase pemenuhan kapasitas \\
16. & Persentase pemenuhan omzet \\
\hline \multicolumn{2}{c}{ Nilai KMO 0,512 } \\
\hline \multicolumn{3}{c}{ Nilai cronbach alpha 0,625} \\
\hline
\end{tabular}

Nilai extraction untuk masing - masing indikator variabel dikatakan valid apabila melebihi nilai 0,40 dan nilai Keiser Mayer Olkin (KMO) lebih dari 0,50 (Ghozali 2006). Suatu indikator dikatakan reliabel apabila nilai cronbach alpha $>$ nilai $r$ tabel (lebih dari 0,6). Apabila nilai koefisien alpha semakin mendekati satu maka hasil yang diperoleh semakin konsisten, sehingga nilai reliabilitasnya tinggi (Sugiyono 2006).

Setelah parameter pengukuran kinerja dinyatakan valid dan reliabel, maka dapat digunakan untuk analisis selanjutnya. Berdasarkan 16 parameter kinerja yang digunakan, maka diperoleh skor rata Rata kinerja dari 30 lumbung pangan sampel. Kinerja lumbung pangan akan diklasifikasikan menjadi tiga, yakni rendah, sedang, dan tinggi. Skor maksimal kinerja lumbung dari 16 parameter yakni 48 poin dan skor minimalnya 16 poin. Kinerja lumbung dibedakan menjadi tiga, yakni kategori rendah jika skornya 16 - 26, kategori sedang jika skornya 27 - 37, dan kategori tinggi jika skornya 38 - 48. Setelah diketahui kinerja dari masing - masing lumbung pangan, maka dibuat persentase berapa jumlah lumbung yang tergolong dalam kinerja rendah, sedang, dan tinggi.

Analisis yang digunakan untuk mengetahui faktor faktor kinerja lumbung pangan yakni analisis deskriptif kuantitatif yang dilakukan dengan metode regresi linier berganda. Metode regresi linier berganda digunakan untuk menganalisis hubungan antarvariabel yang dinyatakan dalam bentuk model (persamaan). Persamaan tersebut menghubungkan variabel terikat (Y) dengan beberapa variabel bebas (X). Variabel terikat pada penelitian ini adalah kinerja lumbung pangan yang diukur dengan skor. Data tersebut belum terdistribusi secara normal, sehingga perlu dilakukan transformasi agar menjadi normal. Transformasi skor kinerja lumbung pangan dilakukan menggunakan rumus sebagai berikut :

$\mathrm{Yt}=\frac{\mathrm{Y}-\overline{\mathrm{Y}}}{\mathrm{Sd}}$

Keterangan :

$\mathrm{Yt}=$ Nilai $\mathrm{Y}$ yang telah ditransformasi

$\mathrm{Y}=$ Nilai atau skor

$\bar{Y}=$ Nilai $Y$ rata - rata

Sd $=$ Standar deviasi dari $Y$

Model persamaan regresi pada penelitian ini yakni

$Y=\beta_{0}+\beta_{1} X_{1}+\beta_{2} X_{2}+\beta_{3} X_{3}+\beta_{4} X_{4}+\beta_{5} D_{1}+\beta_{6} D_{2}$ $+\beta_{7} \mathrm{D}_{3}+\mu$ 
Keterangan :

$\mathrm{Y}=$ Kinerja lumbung pangan (tinggi, sedang, rendah)

$\beta_{0}=$ Intersep

$\beta \mathrm{i}=$ Koefisien parameter regresi yang ditaksir

$\mathrm{X} 1=$ Pendidikan ketua (tahun)

$\mathrm{X} 2=$ Umur lumbung pangan (tahun)

$\mathrm{X} 3$ = Jumlah anggota lumbung pangan (orang)

$\mathrm{X} 4$ = Umur ketua lumbung pangan (tahun)

$\mathrm{D} 1=$ Kemitraan

D1 = 1 bermitra dengan kelompok tani

D1 $=0$ tidak melakukan kemitraan

D2 = Bantuan pemerintah

D2 $=1$, mendapat bantuan pemerintah

D2 $=0$, tidak mendapat bantuan pemerintah

D3 = Jenis lumbung pangan

D3 $=1$, lumbung bentukan pemerintah

D3 $=0$, lumbung pangan swadaya

Hasil regresi diuji terhadap masalah asumsi klasik meliputi multikolinear dan heteroskedastis. Cara yang dapat dilakukan untuk mendeteksi adanya multikolinearitas adalah dengan melihat nilai VIF atau Variance Inflation Factor. Apabila nilai VIF lebih dari 10, maka berarti telah terjadi masalah multikolinearitas, sedangkan jika nilai VIF kurang dari 10 berarti tidak ada masalah multikolinearitas. Masalah heteroskedastisitas diuji menggunakan White Heteroskedasticity Test. Apabila nilai $O b s * R$-squared lebih besar dari 0,05 maka tidak terjadi masalah heteroskedastisitas, sedangkan apabila nilai $O b s^{*} R$-square lebih kecil dari 0,05 maka terjadi heteroskedastisitas (Gujarati 2006).

\section{HASIL PENELITIAN}

Lumbung pangan di Kecamatan Ambarawa berkembang karena adanya inisiatif masyarakat dalam memenuhi kebutuhan pangan terutama untuk menghadapi musim paceklik. Hal tersebut sejalan dengan hasil penelitian Kholiq (2009) yang mengungkapkan bahwa tradisi masyarakat dalam mengumpulkan cadangan pangan masih terjaga, terutama bagi masyarakat petani di pedesaan. Masyarakat petani anggota lumbung di Kecamatan Ambarawa mengumpulkan gabah yang akan digunakan sebagai modal awal lumbung, dengan jumlah berkisar antara $5-100 \mathrm{~kg}$ per orang. Tipe lumbung pangan terdiri dari lumbung kelompok jimpitan, lumbung kelompok tani, lumbung dusun, lumbung rukun tetangga, lumbung kelompok arisan, dan lumbung kelompok agama. Mayoritas (40\%) berupa lumbung kelompok jimpitan. Lumbung pangan mulai berdiri pada tahun 1950, dan mayoritas lumbung $(46,67 \%)$ berdiri pada tahun 1971 - 1990. Jumlah anggota lumbung pangan berkisar antara 5 sampai 300 orang, dengan lumbung dusun sebagai lumbung yang memiliki anggota lebih banyak dibanding tipe lumbung lainnya.

Mayoritas (48,5\%) lumbung pangan (lumbung non-dusun) memiliki anggota antara 19 sampai 32 orang. Terdapat lima lumbung $(16,67 \%)$ yang pernah mendapat bantuan dari pemerintah yakni Lumbung Ngudi Makmur, Lumbung RAS (Rukun Agawi Santoso), Lumbung Nujumulyo, Lumbung Karya Mandiri, dan Lumbung Rawa Indah. Penyimpanan gabah dari mayoritas lumbung $(63,34 \%)$ dilakukan dengan cara dicurah atau dihamparkan. Sebanyak 18 lumbung pangan (60\%) telah bermitra dengan kelompok tani, sedangkan 12 lainnya (40\%) belum melakukan kemitraan. Dari segi pengendalian, mayoritas $(66,7 \%)$ lumbung telah melakukan pengendalian kegiatan secara gabungan, yakni administrasi, rapat bulanan, dan melalui rapat anggota tahunan.

Sebagian besar ketua lumbung pangan $(56,66 \%)$ berada pada kisaran umur 53 - 65 tahun. Tingkat pendidikan terakhir mayoritas ketua lumbung pangan yakni Sekolah Dasar (43,33\%). Mayoritas ketua lumbung pangan berprofesi sebagai petani (sebesar 80\%). Pengalaman menjadi anggota lumbung dari mayoritas ketua lumbung pangan berkisar antara 25 - 33 tahun atau sebesar 53,34 persen. Dari 30 lumbung pangan yang diteliti, hanya terdapat delapan lumbung yang pernah mendapatkan pelatihan bagi anggotanya, meliputi Lumbung Sri Bali, Karya Kitri, Muji Makmur, Karya Mandiri, Rawa Indah, Pelita Jaya, Rukun Agawi Santoso, dan Lumbung Makmur Dusun 1.

\section{Mekanisme Lumbung Pangan dalam Mendukung Ketersediaan Pangan Rumah Tangga}

Mekanisme lumbung pangan dalam mendukung ketersediaan pangan rumah tangga direalisasikan melalui kegiatan simpan pinjam gabah. Para anggota dapat meminjam gabah dari lumbung pangan dengan besaran maksimal antara 100 hingga $1.000 \mathrm{~kg}$ GKG per anggota per tahun. Mayoritas lumbung pangan (40\%) meminjamkan gabahnya sebanyak $100 \mathrm{~kg}$. Jangka waktu peminjaman gabah berlaku selama satu tahun, dan terdapat bunga pinjaman dengan besaran 0 - 30 persen per tahun, dari total gabah yang dipinjam.

Lumbung pangan dibongkar pada saat memasuki musim tanam padi, ketika stok pangan masyarakat 
sudah mulai habis. Keberadaan lumbung pangan dapat mempermudah distribusi pangan bagi rumah tangga. Distribusi pangan merupakan salah satu aspek pendukung ketahanan pangan suatu rumah tangga (Anggraini et al., 2014). Berdasarkan hasil penelitian, diketahui bahwa jumlah pinjaman gabah oleh anggota dari mayoritas lumbung pangan (40\%) berkisar antara $0-200 \mathrm{~kg}$ gabah kering giling. Anggota meminjam gabah untuk memenuhi kebutuhan pangan mereka, sehingga kebutuhan pangan mereka dapat selalu terpenuhi. Hal ini sesuai dengan hasil penelitian Prasmatiwi et al., (2013) yang menyatakan bahwa lumbung pangan banyak memberikan manfaat bagi anggota, terutama untuk meminjam gabah, tempat untuk meminjam modal usahatani atau saprodi, serta sebagai tempat untuk menyimpan gabah.

Lumbung pangan tidak hanya berperan dalam mendukung ketersediaan pangan rumah tangga, tetapi juga memberikan berbagai manfaat bagi para anggota. Lumbung pangan menyediakan pinjaman berbagai jenis pupuk, meliputi pupuk Urea, NPK, TSP, dan SP36. Jumlah pinjaman pupuk berkisar antara $30-45 \mathrm{~kg}$ untuk setiap jenisnya. Lumbung pangan juga menyediaan pinjaman uang dengan kisaran Rp100.000,00 hingga Rp1.000.000,00 yang digunakan oleh anggota sebagai modal usahatani. Pinjaman pupuk dan uang tersebut telah membantu meningkatkan produksi padi para anggota, yang akhirnya juga akan meningkatkan ketersediaan pangan petani.

Manfaat lain yang diperoleh anggota lumbung yakni pembagian hasil usaha, pemberian tunjangan hari raya, santunan bagi anggota yang sakit dan meninggal, serta pembayaran iuran kegiatan desa. Pembagian hasil usaha lumbung pangan dilakukan dalam bentuk bagi hasil dan sistem Sisa Hasil Usaha. Mayoritas (40\%) lumbung memberikan tunjangan hari raya kepada anggota, baik dalam bentuk uang tunai (Rp.100.000,00- Rp.500.000,00) maupun dalam bentuk sembako. Lumbung pangan juga memberikan santunan bagi anggota yang sakit, dalam bentuk uang tunai dengan besaran Rp.100.000,00 - Rp.200.000,00, dan santunan bagi anggota yang meninggal, baik dalam bentuk uang tunai dengan jumlah besaran antara Rp.50.000,00 Rp.500.000,00, beras, perlengkapan pemakaman.

\section{Kinerja Lumbung Pangan Masyarakat}

Skor rata - rata indikator pengukuran kinerja dari 30 sampel lumbung pangan di Kecamatan Ambarawa Kabupaten Prinsewu tersaji pada Tabel 5.
Tabel 5. Skor rata - rata indikator pengukuran kinerja lumbung pangan

\begin{tabular}{|c|c|c|}
\hline No. & Indikator & Skor rata - rata \\
\hline \multirow[t]{6}{*}{1.} & $\begin{array}{l}\text { Manajemen organisas } \\
\text { penguasaan sarana }\end{array}$ & \\
\hline & Peraturan (AD/ART) & 2,56 \\
\hline & Rapat pengurus & 2,20 \\
\hline & Buku administrasi & 2,20 \\
\hline & Lantai jemur & 1,33 \\
\hline & Perangkat humas & 1,56 \\
\hline \multirow[t]{5}{*}{2.} & Skala usaha & \\
\hline & Jenis usaha & 1,83 \\
\hline & Kapasitas lumbung & 2,00 \\
\hline & Omzet lumbung & 1,83 \\
\hline & Persentase anggota & 2,73 \\
\hline \multirow[t]{9}{*}{3.} & Hasil usaha & \\
\hline & Hasil usaha & 1,73 \\
\hline & Insentif pengurus & 1,30 \\
\hline & Pertambahan modal & 1,47 \\
\hline & Keuntungan anggota & 1,43 \\
\hline & Keuntungan lumbung & 1,43 \\
\hline & Pemenuhan kapasitas & 2,03 \\
\hline & Pemenuhan omzet & 1,33 \\
\hline & Total skor * & 28,93 \\
\hline
\end{tabular}

Keterangan : * skor maksimal 48

Berdasarkan Tabel 5 diketahui bahwa total skor rata - rata kinerja dari 30 sampel lumbung pangan di Kecamatan Ambarawa Kabupaten Pringsewu yakni 28,93 yang tergolong dalam kategori sedang. Secara lebih rinci, masing - masing lumbung pangan memiliki skor kinerja yang berbeda. Dari 30 sampel lumbung pangan yang diteliti, mayoritas lumbung pangan tergolong dalam kategori kinerja sedang, yaitu sebesar 53,33 persen, sedangkan sisanya tergolong dalam kinerja rendah yaitu sebesar 46,67 persen.

Menurut jenisnya, lumbung pangan di Kecamatan Ambarawa Kabupaten Pringsewu terbagi menjadi lumbung pangan swadaya dan lumbung pangan bentukan pemerintah. Kinerja lumbung bentukan pemerintah tergolong dalam kategori sedang (sebesar 100\%) dengan skor rata - rata mencapai 36 poin. Secara umum, kinerja lumbung pangan swadaya tergolong dalam kategori sedang dengan skor 27,65 poin, tetapi secara rinci, 48,27 persen lumbung swadaya tergolong dalam kategori kinerja rendah, sedangkan 51,72 persen sisanya tergolong dalam kategori kinerja sedang.

Adapun menurut tipenya lumbung pangan terdiri dari lumbung kelompok jimpitan, lumbung kelompok tani, lumbung kelompok rukun tetangga, lumbung kelompok agama, lumbung kelompok arisan, serta lumbung dusun. Berdasarkan tipenya kinerja lumbung pangan memiliki skor yang berbeda - beda. Sebaran kinerja lumbung pangan tersebut tersaji pada Tabel 6 . 
Tabel 6. Sebaran kinerja lumbung pangan berdasarkan tipe lumbung pangan

\begin{tabular}{llccrr}
\hline \multirow{2}{*}{ No } & Tipe lumbung & \multicolumn{2}{c}{$\begin{array}{c}\text { Skor } \\
\text { rata-rata** }\end{array}$} & \multicolumn{3}{c}{ Kategori Kinerja (\%) } \\
\cline { 4 - 6 } & & Tinggi & Sedang & Rendah \\
\hline 1. & Kelompok jimpitan & 26,41 & 0,00 & 41,67 & 58,33 \\
2. & Kelompok tani & 28,90 & 0,00 & 72,73 & 27,27 \\
3. & Rukun tetangga & 26,00 & 0,00 & 0,00 & 100,00 \\
4. & Kelompok agama & 33,00 & 0,00 & 100,00 & 0,00 \\
5. & Kelompok arisan & 21,00 & 0,00 & 0,00 & 100,00 \\
6. & Lumbung dusun & 32,33 & 0,00 & 66,67 & 33,33 \\
\hline
\end{tabular}

Keterangan : * skor maksimal 48

Mayoritas lumbung pangan berada pada kategori kinerja sedang. Lumbung pangan tersebut telah memiliki berbagai penunjang kegiatan operasional, meskipun belum berjalan secara optimal. Dari segi manajemen organisasi, lumbung pangan telah menjalankan kegiatan sebagai suatu kelembagaan simpan pinjam gabah dengan baik, meskipun 63,34 persen lumbung memiliki peraturan yang masih belum tertulis, seperti pada hasil penelitian Koesoemowardhani (2008).

Berdasarkan aspek sarana penunjang, diketahui bahwa semua lumbung pangan yang diteliti telah memiliki bangunan gudang lumbung yang layak, meskipun bukan bangunan permanen, sehingga penyimpanan gabah telah dilakukan dengan tepat. Kegiatan operasional lumbung pangan ditunjang oleh berbagai sarana penunjang. Peningkatan kinerja lumbung dapat dilakukan tidak hanya dari penguasaan sarana, tetapi juga didukung oleh kualitas sumberdaya manusia yang mengelola sarana tersebut. Aspek sumberdaya manusia dan kelengkapan sarana pendukung merupakan faktor yang harus ditingkatkan sehingga lumbung pangan dapat menjalankan fungsinya dengan lebih maksimal. Hal ini sejalan dengan hasil penelitian Basri (2008) yang menyatakan pengembangan sumberdaya manusia dan sarana prasarana, adalah salah satu strategi agar kelembagaan lumbung pangan masyarakat dalam meningkatkan ketahanan pangan dapat tercapai.

\section{Faktor-faktor yang Mempengaruhi Kinerja Lumbung Pangan di Kecamatan Ambarawa Kabupaten Pringsewu}

Kinerja lumbung pangan di Kecamatan Ambarawa dipengaruhi oleh berbagai faktor, yang meliputi pendidikan ketua, umur lumbung, jumlah anggota lumbung, umur ketua lumbung, kemitraan, bantuan pemerintah, dan jenis lumbung. Faktor - faktor tersebut diuji dengan analisis regresi linier berganda menggunakan program SPSS. Hasil analisis regresi linier berganda tersaji pada Tabel 7.
Tabel 7. Hasil regresi faktor - faktor yang mempengaruhi kinerja lumbung pangan

\begin{tabular}{|c|c|c|c|c|c|}
\hline No & Variabel (x) & B & t-hit & Sig & VIF \\
\hline & Constant & $-0,497$ & $-0,370$ & 0,715 & \\
\hline 1. & Pendidikan ketua & 0,009 & 0,142 & 0,889 & 1,077 \\
\hline 2. & Umur lumbung & $0,030 * *$ & 2,085 & 0,049 & 1,216 \\
\hline 3. & Jumlah anggota & $0,008 * *$ & 2,304 & 0,031 & 1,255 \\
\hline 4. & Umur ketua & $-0,011$ & $-0,524$ & 0,605 & 1,332 \\
\hline 5. & Kemitraan & $-0,246$ & $-0,738$ & 0,468 & 1,088 \\
\hline 6. & Bantuan pemerintah & 0,059 & 0,141 & 0,889 & 1,250 \\
\hline 7. & Jenis lumbung & $2,398 * *$ & 2,432 & 0,024 & 1,275 \\
\hline
\end{tabular}

Faktor - faktor yang berpengaruh terhadap kinerja lumbung pangan yakni umur lumbung, jumlah anggota lumbung, dan jenis lumbung. Koefisien determinasi $\left(R^{2}\right)$ yang diperoleh sebesar 0,440 yang berarti bahwa 44 persen variasi tingkat kinerja lumbung pangan di Kecamatan Ambarawa dapat dijelaskan oleh variabel independen. Nilai F-hit sebesar 2,466 dengan signifikan sebesar 0,050 berarti bahwa secara bersama - sama, variabel pendidikan ketua (X1), umur lumbung pangan (X2), jumlah anggota (X3), umur ketua lumbung(X4), kemitraan (D1), bantuan pemerintah (D2), dan jenis lumbung pangan (D3) berpengaruh nyata terhadap kinerja lumbung dengan tingkat kepercayaan 95 persen.

Nilai VIF pada Tabel 7 lebih kecil dari 10, yang berarti bahwa hasil regresi terbebas dari masalah multikolinieritas. Multikolinearitas juga dapat diketahui dengan melihat nilai matriks korelasi dari variabel bebas. Jika nilai koefisien korelasi lebih dari 0,80 berarti terdapat multikolinearitas pada hasil regresi (Gujarati 2006). Hasil penelitian menunjukkan bahwa semua nilai koefisien korelasi lebih kecil dari 0,80 sehingga disimpulkan bahwa hasil analisis regresi terbebas dari masalah multikolinear. Hasil uji White heteroskedasticity menunjukkan nilai $O b s^{*} R$-squared lebih dari 0,05 $(0,1351)$ sehingga dapat disimpulkan tidak ada masalah heteroskedastisitas pada hasil regresi.

Umur lumbung pangan (X2) berpengaruh positif terhadap kinerja lumbung pangan dengan taraf kepercayaan sebesar 95 persen. Umur lumbung pangan memiliki nilai koefisien positif yang berarti bahwa apabila terjadi peningkatan umur lumbung maka akan menyebabkan peningkatan kinerja dari lumbung pangan tersebut. Hal tersebut terjadi karena suatu lumbung yang telah beroperasi sejak lama memiliki pengalaman dalam melakukan berbagai jenis usaha.

Jumlah anggota berpengaruh terhadap kinerja lumbung pangan dengan taraf kepercayaan sebesar 
95 persen. Nilai koefisien bertanda positif yang berarti bahwa apabila terjadi peningkatan jumlah anggota akan menyebabkan peningkatan kinerja lumbung pangan. Lumbung dengan anggota yang banyak memiliki skala usaha yang tinggi karena para anggota akan berpartisipasi dalam berbagai kegiatan lumbung pangan. Jenis lumbung pangan mempengaruhi kinerja lumbung pangan dengan taraf kepercayaan sebesar 95 persen. Jenis lumbung pangan merupakan variabel Dummy. Jenis lumbung pangan memiliki nilai koefisien yang bertanda positif yang berarti bahwa lumbung pangan bentukan pemerintah memiliki kinerja yang lebih tinggi dibanding lumbung swadaya.

\section{KESIMPULAN}

Mekanisme lumbung pangan direalisasikan dalam kegiatan simpan pinjam. Anggota menyimpan gabah sebagai modal awal sebesar 5 - $100 \mathrm{~kg}$ per orang, dan dapat meminjam gabah dengan jumlah pinjaman $100-1.000 \mathrm{~kg}$ per tahun. Jangka waktu peminjaman gabah berlangsung selama satu tahun. Pada saat mengembalikan pinjaman, anggota lumbung harus membayar bunga pinjaman dalam bentuk gabah sebesar 0 - 30 persen dari jumlah gabah yang dipinjam, sesuai ketentuan masing masing lumbung pangan. Sebanyak 53,33 persen lumbung pangan masuk dalam kategori kinerja sedang, dan 46,67 persen sisanya masuk dalam kategori kinerja rendah. Adapun faktor - faktor yang mempengaruhi kinerja lumbung pangan yakni umur lumbung pangan, jumlah anggota lumbung pangan, dan jenis lumbung pangan.

\section{DAFTAR PUSTAKA}

Anggraini M, Zakaria WA, dan Prasmatiwi FE. 2014. Ketahanan Pangan Rumah Tangga Petani Kopi di Kabupaten Lampung Barat. JIIA, Vol.2, No.2, April 2014. http://jurnal.fp. unila.ac.id/index.php/JIA/article/view/737/67 8 [5 April 2017].

BPS [Badan Pusat Statistik] Republik Indonesia. 2016. Statistik Indonesia tahun 2016. BPS. Jakarta.

Basri M. 2008. Studi Kelembagaan Lumbung Pangan Masyarakat di Kecamatan Sumbawa Provinsi Nusa Tenggara Barat. [Thesis]. Sekolah Pasca Sarjana Institut Pertanian Bogor. Bogor.
Departemen Pertanian. 2008. Pedoman Umum Pemberdayaan Kelembagaan Lumbung Pangan Masyarakat. Departemen Pertanian Republik Indonesia. Jakarta.

Ghozali I. 2006. Aplikasi Analisis Multivariate dengan Program SPSS. Badan Penerbit Universitas Diponegoro. Semarang.

Gujarati D. 2006. Dasar - dasar Ekonometrika. Erlangga. Jakarta.

Irianto $\mathrm{H}$ dan Mardikanto T. 2010. Metode Penelitian dan Evaluasi Agribisnis. Program Studi Agribisnis UNS Solo. Solo.

Kholiq, Hardinsyah, dan Djamaludin MD. 2009. Persepsi dan partisipasi masyarakat dalam pengebangan lumbung pangan masyarakat di Kabupaten Lampung Barat. Jurnal Gizi dan Pangan:3(3) http://repository.ipb.ac.id /hand le/123456789/52535 [20 Sept 2016].

Koesoemowardani N dan Sumardjo. 2008. Peran Komunikasi dalam pengembangan lumbung untuk meningkatkan ketahanan pangan masyarakat : kasus lumbung pangan di Ciamis Jawa Barat. Jurnal Komunikasi Pembangunan:6(2) jurnal.ipb.ac.id/index. php /jurnalkmp/article/viewFile/5668/429. [20 September 2016].

Mardalis A, dan Rosyadi I. 2015. Model revitalisasi fungsi dan peran lumbung pangan desa untuk meningkatkan ketahanan pangan. University Research Colloquium 2015. ISSN 2407-9189. https://publikasi ilmiah.ums.ac. id/bitstream/handle/11617/5128/12.pdf?seque nce $=1 \&$ is Allowed $=y$. [20 September 2016]

Nasdian FT. 2006. Kemitraan dalam Tata Pemerintahan Desa dan Pemberdayaan Komunitas Perdesaaan dalam Perspektif Kelembagaan dalam Pembaharuan Tata Pemerintahan Desa Berbasis Lokalitas dan Kemitraan. PSP3 - IPB dan Partnership of Governance Reform in Indonesia - UNDP.

Prasmatiwi FE, Rosanti N, dan Listiana I. 2013. Kajian cadangan pangan rumah tangga petani padi di Provinsi Lampung. Prosiding Seminar Nasional Sains \& Teknologi V (Satek \& Indonesia Hijau) 19-20 November 2013 halaman 1103-1112 ISBN : 97 8-979-8510-7 l-7. http://repository.lppm.unila.ac.id/756/. [5 April 2017].

Saryono. 2010. Metode Penelitian Kualitatif. PT Alfabeta. Bandung.

Sugiyono. 2006. Statistika untuk Penelitian. Alfabeta. Bandung. 